УДК 616.366-003.7+618.1]-089.819

DOI 10.11603/24116-4944.2020.2.11839

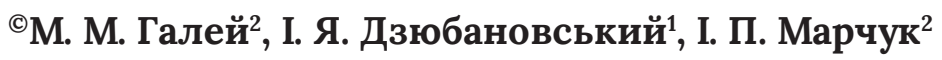 \\ ${ }^{1}$ Тернопільсъкий національний медичний університет ілені І. Я. Горбачевсъкољо \\ МОЗ України \\ ${ }^{2}$ КП «Волинсъка обласна клінічна лікарня»
}

\title{
ТЕХНІКА ВИКОНАННЯ СИМУЛЬТАННИХ ОПЕРАЦІЙ ПРИ ПОЄДНАНІЙ ГІНЕКОЛОГІЧНІЙ ПАТОЛОГІЇ ІЗ ЖОВЧНОКАМ'ЯНОЮ ХВОРОБОЮ
}

Мета дослідження - порівняти розроблену техніку симультанних операційних втручань із звичайною технікою лапароскопічної холецистектомії за такими показниками, як безпека, час операції, час стаціонарного лікування, рівень ускладнень, втома хірургів після операцій.

Матеріали та методи. У період із 2015 до 2019 р. у ВІМдл ВОКл 284 пацієнтам були виконані операції. Хворих було поділено на дві групи: перша - 72 пацієнтки із поєднаною гінекологічною патологією (ГП) та жовчнокам'яною хворобою (ЖКХ) та друга - 212 пацієнток лише із жовчнокам'яною хворобою. Статистику опрацьовано у програмі «Statistica v12.6». Використано аналіз критерію Шапіро-Уілка, статистичні методи порівняння Манна-Уїтні, або U-критерій та ANOVA. Критичний рівень значущості $p$ у всіх розрахунках визначено як 0,05.

Результати дослідження та їх обговорення. Час операції склав $(53 \pm 4,18)$ Хв $(31-66$ хв) для першої групи і $(41 \pm 3,77)$ хв (27-60 хв) - для другої. Зростання на 12 хв, або 23,6 \%. Термін стаціонарного лікування склав 3,29 (2-8) дня у першій групі проти 3,32 (2-8) дня у другій ( $p=0,941)$. Рівень ускладнень в обох групах був зіставним і не відрізнявся значуще ( $p=0,966)$. Зміна критичної частоти злиття мерехтінь (КЧЗМ) у першій групі становила 2,25 Гц, а у другій - 2,18 Гц (p=0,928). Відносна сила знизилась у досліджуваній групі на 5,96 \%, а в контрольній - на 5,73 \% (p=0,970). Різниця у показниках між групами була незначущою, крім часу операції. Зростання було незначним, що не може конкурувати із показниками окремої операції.

Висновки. 1. Виконання симультанних лапароскопічних втручань розробленою технікою для лікування жовчнокам'яної хвороби та поєднаної хірургічної гінекологічної патології не приводить до збільшення тривалості лікування у стаціонарі, збільшення кількості ускладнень, фрізичної чи психологічної втоми хірургів. 2. Збільшення тривалості операції не було критичним і не може конкурувати в часі з однією окремою операцією для цієї патології. 3. Симультанні лапароскопічні операції $€$ оптимальними для хворих із поєднаною ЖКХ та ГП, а техніка, розроблена на базі ВІМдЛ ВОКЛ, є оптимальним вибором для виконання таких операцій.

Ключові слова: лапароскопія; симультанно; ЖКХ; гінекологія; міома.

ТЕХНИКА ВЫПОЛНЕНИЯ СИМУЛЬТАННЫХ ОПЕРАЦИЙ ПРИ СОЧЕТАННОЙ ГИНЕКОЛОГИЧЕСКОЙ ПАТОЛОГИИ С ЖЕЛЧНОКАМЕННОЙ БОЛЕЗНЬЮ

Цель работы - сравнить разработанную технику симультанных оперативных вмешательств с обычной техникой лапароскопической холецистэктомии по таким показателям, как безопасность, время операции, время стационарного лечения, уровень осложнений, усталость хирургов после операций.

Материалы и методы. В период с 2015 по 2019 г. в ОИМдл ВОКБ 284 пациенткам были выполнены операции. Больные были поделены на две группы: первая - 72 пациентки с сочетанной гинекологической патологией (ГП) и желчнокаменной болезнью (ЖКБ) и вторая - 212 пациенток только с желчнокаменной болезнью. Статистика проработана в программе «Statistica v12.6». Использованы анализ критерия Шапиро-Уилка и статистические методы сравнения Манна-Уитни, или U-критерий и ANOVA. Критический уровень значимости р во всех расчетах определен как 0,05.

Результаты исследования и их обсуждение. Время операции составило $(53 \pm 4,18)$ мин $(31-66$ мин) для первой группы и $(41 \pm 3,77)$ мин (27-60 мин) - для второй. Рост на 12 мин, или 23,6 \%. Срок стационарного лечения составил 3,29 (2-8) дня в первой группе против 3,32 (2-8) дня во второй (p=0,941). Уровень осложнений в обеих группах был сопоставим и не отличался значимо ( $\mathrm{p}=0,966)$. Изменение критической частоты слияния мельканий $($ КчСМ) в первой группе составило $2,25$ Гц, а во второй - 2,18 Гц ( $p=0,928)$. Относительная сила снизилась в исследуемой группе на 5,96 \%, а в контрольной - на 5,73 \% (p=0,970). Разница в показателях между группами была незначимой, кроме времени операции. Рост был незначительным, что не может конкурировать с показателями отдельной операции.

Выводы. 1. Выполнение симультанных лапароскопических вмешательств разработанной техникой для лечения желчнокаменной болезни и сочетанной хирургической гинекологической патологии не приводит к увеличению продолжительности лечения в стационаре, увеличению количества осложнений, физической или психологической усталости хирургов. 2. Увеличение продолжительности операции не было критическим и не может конкурировать по времени с одной отдельной операцией для этой патологии. 3. Симультанные лапароскопические операции являются оптимальными для больных с сочетанной ЖКХ и ГП, а техника, разработанная на базе ОИМДЛ ВОКБ, является оптимальным выбором для выполнения таких операций.

Ключевые слова: лапароскопия; симультанно; ЖКБ; гинекология; миома.

TECHNIQUE OF SIMULTANEOUS OPERATIONS IN COMBINED GYNECOLOGICAL PATHOLOGY WITH GALLSTONE DISEASE

The aim of the study - to compare the developed technique of simultaneous surgical interventions with the usual technique of laparoscopic cholecystectomy on such indicators as safety, time of operation, hospital stay time, frequency of complications, fatigue of surgeons after operations. 
Materials and Methods. In the period from 2015 to 2019, 284 patients underwent surgery. Patients were divided into two groups: group 1 - 72 patients with combined gynecological pathology and gallstone disease and 212 patients with gallstone disease only. Statistics were processed in the program "Statistica v12.6". Shapiro-Wilk test analysis, and statistical methods of Mann-Whitney comparison, or U-test and ANOVA were used. The critical significance level in all calculations is defined as $p 0.05$.

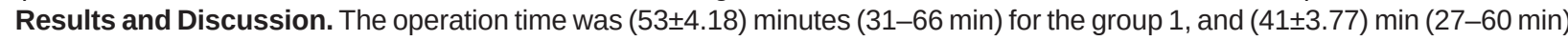
for the group 2. Growth of 12 minutes, or $23.6 \%$. The hospital stay time was 3.29 (2-8) days in the group 1 against 3.32 (2-8) days in the group $2(p=0.941)$. The frequency of complications in both groups was comparable and did not differ significantly ( $p=0.966)$. The change in CFFF in the group 1 was $2.25 \mathrm{~Hz}$, and in the group $22.18 \mathrm{~Hz}(p=0.928)$. The relative strength decreased in the study group by $5.96 \%$ and in the control group by $5.73 \%(p=0.970)$. The difference between the groups was insignificant except for the time of the operation. The growth was insignificant, which could not compete with the performance of a single operation.

Conclusions. 1. Performing simultaneous laparoscopic interventions developed by the technique for the treatment of gallstones and combined surgical gynecological pathology does not increase the duration of treatment in the hospital, increase the number of complications, physical or psychological fatigue of surgeons. 2. The increase in the duration of the operation was not critical and could not compete in time with a single operation for this pathology. 3. Simultaneous laparoscopic operations are optimal for patients with combined housing and communal services and GP, and the technique developed on the basis of Volyn Regional Clinical Hospital is the optimal choice for such operations.

Key words: laparoscopy; simultaneous; gallstone disease; gynecology; myoma.

ВСтУп. Жовчнокам'яна хвороба (ЖКХ) уражає до $30 \%$ дорослих у різних частинах світу [1]. Статистика свідчить, що до 20 \% дорослих хворих мають вже діагностовану ЖКХ, ще 1-3 \% нових випадків діагностують щорічно, із цих хворих половина звернеться до закладів охорони здоров'я через ускладнення чи загострення ЖКХ, що стає причиною до 10000 смертей на рік, з яких до $70 \%$ складуть саме такі ускладнення гострого холецистолітіазу чи/та холедохолітіазу, як гострий біліарний панкреатит [2]. Після 55 років до 68,6 \% жінок і до 22,4 \% чоловіків мають конкременти жовчного міхура [2]. Значна поширеність і небезпечні ускладнення роблять дослідження щодо лікування цієї патології актуальними. Близько 22-25 \% пацієнтів із ЖКХ мають супутню хірургічну патологію органів черевної порожнини [3]. Малоінвазивні методи, сучасні техніки і протоколи ERAS роблять хірургічне операційне лікування не лише безпечним і легким для хворого, а й пріоритетним над консервативною курацією пацієнта [4]. 3 огляду на високу частоту коморбідності ЖКХ, нерідкими є і поєднання останньої із гінекологічною хірургічною патологією. Доброякісні новоутворення тіла матки, яєчників, сальпінгіти (піосальпінкс, гідросальпінкс) $€$ досить поширеними, лише міома матки діагностується у 20-25\% дорослого жіночого населення [5-8]. При невчасному виявленні та хірургічному лікуванні такі патології теж можуть викликати загрозливі стани та ускладнення, а також стати причиною до $60 \%$ гістеректомій [9]. Саме тому рекомендовано проводити хірургічне лікування якнайшвидше після виявлення патології, особливо 3 теперішнім розвитком лапароскопії, що дозволяє малоінвазивно виконувати операції з мінімальними ризиками та тривалістю реабілітації, використовуючи підхід ERAS [10].

3 огляду на значну поширеність гінекологічної патології, паралельно з тим, що ЖКХ частіше уражає жінок, актуальним $€$ питання ефективної паралельної медичної допомоги пацієнткам, у яких виявлено комбінацію хірургічної гінекологічної патології та ЖКХ. Водночас це питання набуває особливої ваги на фоні сучасних вимог до оптимізації медицини, рекомендацій щодо зниження тривалості стаціонарного перебування хворих, кількості їх звернень, витрат на лікування [11]. Особливо наполегливо рекомендовано виконувати паралельне лікування пацієнтам, які потрапили до стаціонару з різних причин, усіх виявлених патологій паралельно (особливо хірургічних), що приводить до збільшення ефективності, зменшення сумарного часу, витраченого на лікування, та ресурсів, задіяних у цей час в розрахунку на одного пацієнта (не останню роль відіграє і зниження кількості ускладнень зі зменшенням сумарного часу перебування у стаціонарі) [12]. Постає питання розвитку симультанних лапароскопічних операційних втручань для лікування ЖКХ та супутньої гінекологічної патології, як найважливішої складової стаціонарного лікування, щоб задовольнити вимоги до раннього хірургічного лікування жовчнокам'яної хвороби $(Ж K X)[1,4,13]$ та гінекологічної хірургічної патології (ГП) одночасно [9, 10].

МЕТА ДОСЛІДЖЕННЯ - порівняти розроблену техніку симультанних операційних втручань із звичайною технікою лапароскопічної холецистектомії за такими показниками, як безпека, час операції, час стаціонарного лікування, рівень ускладнень, втома хірургів після операцій.

МАТЕРІАЛИ ТА МЕТОДИ. У відділенні інвазивних методів діагностики та лікування Волинської обласної клінічної лікарні (ВІМДЛ ВОКЛ) розроблено техніку симультанних лапароскопічних операцій для лікування ЖКХ та ГП. Техніка дозволяє виконувати лапароскопічну холецистектомію та операції з видалення міоми тіла матки, розрішення піо- гідросальпінксу, видалення кіст яєчників симультанно: без втрати часу чи негативного впливу на ергономічну складову операції. Ергономіка у цьому дослідженні відіграє вирішальну роль, адже при зниженні ергономічності операції, знижується й ефективність [14]. Зростає навантаження на хірурга, як фрізичне, так і психоемоційне, що може мати негативні наслідки [14].

Виконано ретроспективне дослідження пацієнток, пролікованих у ВІМДЛ ВОКЛ у період із 2015 до 2019 року з приводу ЖКХ та ГП. Напрацьована статистична база даних включала у себе інформацію про 284 пацієнток. Дані аналізували за допомогою програми «Statistica®» (v.12.6 StatSoft'M USA). Сорормовано дві групи за принципом коморбідності. Перша група була досліджуваною і включала 72 пацієнток, яким було виконано симультанне операційне втручання, використовуючи власну розроблену техніку. Друга група була контрольною і включала 212 пацієнток, яким було виконано лише лапароскопічну холецистектомію (табл. 1). 
Акушерство та гінекологія -

Таблиця 1. Розподіл хворих за віком у групах

\begin{tabular}{|l|c|c|c|c|}
\hline \multirow{2}{*}{ Група } & \multicolumn{4}{|c|}{ Вік } \\
\cline { 2 - 5 } & $25-44$ & $45-60$ & $60-75$ & $75-90$ \\
\hline $\begin{array}{l}\text { Група 1 } \\
(\mathrm{n}=72)\end{array}$ & $21(29,2 \%)$ & $35(48,6 \%)$ & $14(19,4 \%)$ & $2(2,8 \%)$ \\
\hline $\begin{array}{l}\text { Група 2 } \\
(\mathrm{n}=212)\end{array}$ & $65(30,7 \%)$ & $107(50,5 \%)$ & $22(10,4 \%)$ & $18(8,5 \%)$ \\
\hline
\end{tabular}

Порівняння технік відбувалось шляхом оцінки ергономічної складової операційного втручання, а саме: втоми хірургів до та після виконаного операційного втручання, середньої зміни показника; та шляхом оцінки ефективності лікування, а саме: рівня ускладнень та тривалості операційного лікування, часу стаціонарного лікування.

Втому оцінювали шляхом визначення відносної сили (у \%) до та після операції для фрізичної втоми та визначенням критичної частоти злиття мерехтінь (КЧЗМ) (у Гц) до та після операції для психоемоційної втоми (як показник стану нервової системи).

Після аналізу робіт наших колег та вивчивши напрям дії сил, які виникають у м'язово-апоневротичному шарі пацієнта під час лапароскопічної операції, та сил, що прикладаються до робочих інструментів, розробили найоптимальніше стереометричне співвідношення введення портів для виконання симультанних лапароскопічних операційних втручань, що дозволяє виконувати лапароскопічну холецистектомію та гінекологічні операції паралельно та мінімізувати ефект фрехтування, покращити доступність об'єкта операції, зменшити психоемоційне напруження та фрізичне навантаження хірургів.

Обстеження в обох групах було стандартним, згідно із затвердженим лікарняним протоколом. Передопераційне обстеження тривало 1 день до операції та включало аналіз лабораторних показників (загальний аналіз крові та сечі, біохімічний аналіз крові, коагулограму та ін.), аналіз результатів інструментального обстеження (УЗД ОЧП та МТ, ФГДС, МРТ, при необхідності й інші), а також дані анамнезу та огляду пацієнтів сумісно із лікарем-гінекологом.

Передопераційна підготовка не відрізнялась у всіх пацієнтів та регламентована протоколом ERAS Society $[10,15]$. Підготовка до гінекологічних операцій, операцій на жовчному дереві та при їх поєднанні однакова. Операційне обладнання, що було використане для операцій у всіх випадках, - MGB ${ }^{\text {тм }}$ (відеокомлекс Aristo V-3®).

Використовували аналіз критерію Шапіро-Уілка, із розрахунком середнього арифрметичного (М) і стандартного відхилення (S) та статистичні методи порівняння Манна-Уїтні, або U-критерій та ANOVA. Критичний рівень значущості $p$ у всіх розрахунках визначено як 0,05.

РЕЗУЛЬТАТИ ДОСЛІДЖЕННЯ ТА ЇХ ОБГОВОРЕННЯ. Розроблено оптимальну стереометричну конорігурацію портів для виконання лапароскопічної холецистектомії із симультанною гінекологічною операцією (рис. 1).

Холецистектомія виконується як перший етап. Для пацієнтів з ожирінням можливе використання інструментів із довжиною тіла 450 мм.

При такому розміщенні портів зберігаються принципи пересічення лапароскопа з органами-мішенями на відстані в $1 \frac{1}{2}$ його довжини, збереження кута між робочими інструментами у $60-90^{\circ}$, введення портів під кутом у $30-45^{\circ}$ відносно площі операційного стола, що вважають дуже важливим для ергономіки і в роботі наших колег [14]. Під час операції також важливо користуватись наробками дослідників, що опубліковані попередньо. Дослідники ергономіки у лапароскопії наголошують на необхідності ергономіки як важливого фрактора ефективності техніки хірургічного втручання, і варто дотримуватись правил: збереження принципу прямої лінії (співвісність хірург-мішень-екран), підйом столу на висоту ледве зігнутих рук хірурга, розміщення екрана у $25^{\circ}$ підйомі відносно очей хірурга [14].

Таке співвідношення не випадкове. Його збереження між портами дозволяє хірургу маніпулювати інструментами, не входячи в незручні нефізіологічні положення, що збільшують фрізичне і психоемоційне навантаження. Самі ж інструменти в такому варіанті розміщуються найбільш ефрективно, коли робочі поверхні зіставно працюють у зоні операційного втручання, а лапароскоп забезпечує огляд «за маніпулятором», що дозволяє найбільш чітко й адекватно сприймати і координувати свої дії хірургам, адже в такому випадку інструменти стають продовженням руки. Але однаково важливими є і місця введення портів на тілі пацієнта, враховуючи індивідуальні анатомічні особливості, а також дані, отримані інструментально, включаючи інтраопераційні.

Красномовними є отримані дані. Тривалість операційного втручання у групі симультанних лапароскопічних операцій склала $(53 \pm 4,18)$ хв $(31-66$ хв), тоді як у групі звичайної холецистектомії середній час був $(41 \pm 3,77)$ хв (27-60 хв). Зростання склало 12 хв, або 23,6 \%. 3ростання часу не покриває тривалість самої операції, що продемонстровано у контрольній групі, а також часу, заявленого у дослідженнях наших колег $[16,17]$. Такі дані дозволяють говорити про більшу ефективність виконання симультанних операцій порівняно із двома окремими

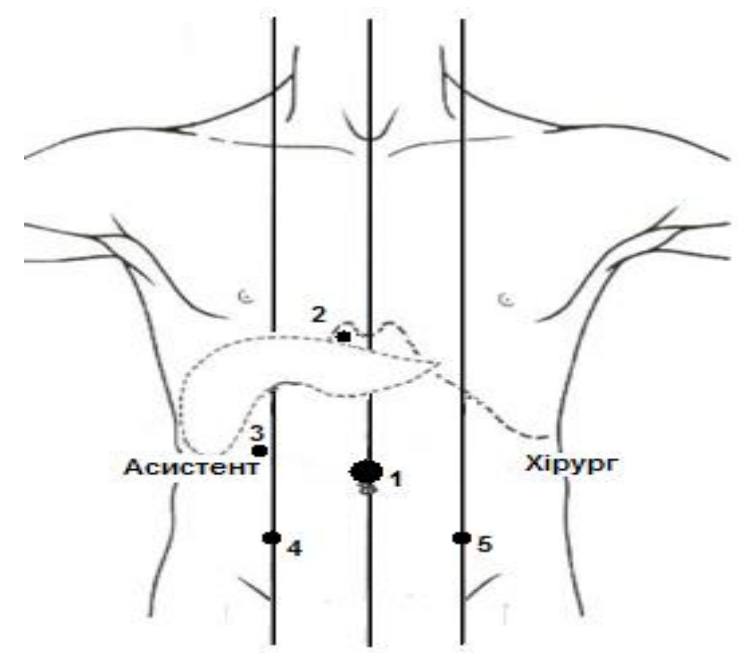

Рис. 1. Схема введення портів для виконання симультанних лапароскопічних холецистектомії та гінекологічної операції: 1 - 10-міліметровий порт для лапароскопа; 2 - 5-міліметровий порт для інструмента хірурга (використовується для холецистектомії); 3 -5-міліметровий порт для інструмента хірурга під час холецистектомії та асистента для гінекологічних операцій; 4 - 5-міліметровий порт для інструмента асистента під час холецистектомії та інструмента хірурга для гінекологічних операцій; 5 - 5-міліметровий порт для інструмента хірурга (використовується для гінекологічних операцій). 
Акушерство та гінекологія

(особливо враховуючи час на доступ та зашивання ран, анестезію, підготовку та ризик злук при повторній операції і т. ін.).

Термін перебування пацієнта у стаціонарі в досліджуваній групі склав 3,29 (2-8) дня, тоді як у контрольній 3,32 (2-8) дня. Статистично значущої різниці у термінах стаціонарного лікування не виявлено $(p=0,941)$. Такий термін стаціонарного лікування $є$ добрим показником для лапароскопічних операцій $[10,15]$. Дослідження вказують на необхідність досягнення раннього виписування при відсутності протипоказань $[10,15]$. Тобто, виконання симультанних операцій не збільшує тривалість госпіталізації, порівняно зі звичайною холецистектомією, і ризики, пов'язані з тривалістю перебування.

Рівень ускладнень в обох групах (табл. 2) був зіставним та не мав статистично значущої кореляції $(p=0,966)$, що вказує на профріль безпеки симультанних операцій на рівні із звичайною стандартною лапароскопічною холецистектомією. Ускладнення під час операцій, що траплялися в обох групах, були звичайними та поширеними і в дослідженнях наших колег [18].

Визначення фрізичної та психоемоційної втоми у хірургів виконували до та після операції для визначення зміни цих показників та впливу на них операції. Критична частота злиття мерехтінь характеризує стан нервової системи. До операцій це показник складав (у середньому) 43,77 та 43,59 Гц у першій та другій групі відповідно. Після операції цей показник складав 41,52 та 41,41 Гц у першій та другій групі відповідно. Зміна КЧЗМ у першій групі становила 2,25 Гц, а в другій групі - 2,18 Гц. Різниця статистично незначуща $(p=0,928)$. Відносна ж фрізична сила характеризує показник орізичної втоми. До операції цей показник складав 72,31 та 71,85 \% для першої та другої груп відповідно. Після операції цей показник складав 66,35 та 66,12 \% для першої та другої груп відповідно. Зміна у досліджуваній групі склала 5,96 \%, а в контрольній -

\section{СПИСОК ЛІТЕРАТУРИ}

1. Nationwide epidemiological study of severe gallstone disease in Taiwan / J. Huang, C. H. Chang, J. L. Wang [et al.] // BMC. Gastroenterology. - 2009. - Vol. 9. - Article number 63.

2. Impact of the Tokyo guidelines on the management of patients with acute calculous cholecystitis / S. W. Lee, S. S. Yang, C. S. Chang, H. J. Yeh // J. Gastroenterol. Hepatol. - 2009. Vol. 24 (12). - P. 1857-1861.

3. Comparison of comorbidity scores in predicting surgical outcomes / H. B. Mehta, F. Dimou, D. Adhikari [et al.] // Medical Care. - 2016. - Vol. 54 (2). - P. 180-187.

4. Severity of acute cholecystitis and risk of iatrogenic bile duct injury during cholecystectomy, a population-based casecontrol study / B. Törnqvist, A. Waage, Z. Zheng [et al.] // World J. Surg. - 2016. - Vol. 40 (5). - P. 1060-1067.

5. Mitchell C. Pelvic inflammatory disease: current concepts in pathogenesis, diagnosis and treatment / C. Mitchell, M. Prabhu // Infect. Dis. Clin. North Am. - 2013. - Vol. 27 (4). - P. 793-809.

6 . Epidemiology of uterine myomas: a review / R. Sparic, L. Mirkovic, A. Malvasi, A. Tinelli // Int. J. Fertil. Steril. - 2016. Vol. 9 (4). - P. 424-435.

7. Жулкевич І. В. Персоналізація в онкології: індивідуальний підхід до профілактики тромбоемболічних ускладнень при пангістеректомії / І. В. Жулкевич, Б. Д. Кривокульський // Вісник соціальної гігієни та організації охорони здоров'я України. - 2018. - № 4. - С. 11-18.
Таблиця 2. Ускладнення у групах

\begin{tabular}{|l|c|c|}
\hline \multicolumn{1}{|c|}{ Види ускладнень } & Група 1 & Група 2 \\
\hline Внутрішньочеревна кровотеча & $1(1,4 \%)$ & $2(1 \%)$ \\
\hline Диспозиція кліпси/лігатури & $0(0 \%)$ & $2(1 \%)$ \\
\hline $\begin{array}{l}\text { Ускладнення при видаленні } \\
\text { препарату }\end{array}$ & $1(1,4 \%)$ & $4(1,9 \%)$ \\
\hline \hline
\end{tabular}

$5,73$ \%. Різниця статистично незначуща ( $p=0,970)$. Зміни у показниках не відрізнялись та характеризували звичайну виробничу втому, характерну для професії «хірург», та в усіх випадках не перевищували $15 \%$, що не викликало перевтоми і вимагало 15-хвилинної перерви трудової діяльності згідно із регламентом гігієни праці [19].

ВИСНОВКИ. 1. Виконання симультанних лапароскопічних втручань розробленою технікою для лікування жовчнокам'яної хвороби та поєднаної хірургічної гінекологічної патології не приводить до збільшення тривалості лікування у стаціонарі, збільшення кількості ускладнень, фрізичної чи психологічної втоми хірургів.

2. Збільшення тривалості операції не було критичним і не може конкурувати в часі з однією окремою операцією для цієї патології.

3. Симультанні лапароскопічні операції є оптимальними для хворих із поєднаною ЖКХ та ГП, а техніка, розроблена на базі ВІМДЛ ВОКЛ, $є$ оптимальним вибором для виконання таких операцій.

ПЕРСПЕКТИВИ ПОДАЛЬШИХ ДОСЛІДЖЕНЬ. Продовжити напрацювання та аналіз даних для збільшення статистичних даних, що дозволить точніше оцінити можливі ризики ускладнень. Проведення дослідження ефективності та безпеки симультанних лапароскопічних операцій для онкопатології у гінекології. Оцінка економічного потенціалу симультанних лапароскопічних операцій для лікування гінекологічної патології у поєднанні із хірургічними захворюваннями ОЧП.

8. Вивчення впливу віку та індексу коморбідності на ризик тромботичних ускладнень у хворих на рак ендометрія на доопераційному етапі / Б. Д. Кривокульський, І. В. ЖулкеВич, Д. Б. Кривокульський, Л. В. Шкробот // Вісник наукових досліджень. - 2018. - № 2 (91). - С. 151-153. https://doi. org/10.11603/2415-8798.2018.2.9212..19.

9. Hysterectomy throughout history / R. Sparić, G. Hudelist, M. Berisava [et al.] //Acta Chir. Iugosl. -2011. - Vol. 58 (4). -P. 9-14.

10. Guidelines for perioperative care in gynecologic/oncology: Enhanced Recovery After Surgery (ERAS) Society recommendations-2019 update / G. Nelson, J. Bakkum-Gamez, E. Kalogera [et al.] // Int. J. Gynecol. Cancer. - 2019. - Vol. 29 (4). - P. 651-668.

11. Overlapping Surgery: 2 Years Later / J. Guan, M. Karsy, A.A. Brock, [et al.] // Neurosurgery. - 2018. - Vol. 65 (CN suppl_1). - P. 55-57.

12. Levin P. E. Overlapping and concurrent surgery: a professional and ethical analysis / P. E. Levin, D. Moon, D. E. Payne // J. Bone Joint Surg. Am. - 2017. - Vol. 99 (23). - P. 2045-2050.

13. Surgical treatment of patients with acute cholecystitis: Tokyo guidelines / Y. Yamashita, T. Takada, Y. Kawarada [et al.] // J. Hepatobiliary Pancreat. Surg. - 2007. - Vol. 14 (1). - P. 91-97.

14. Sánchez-Margallo F. M. Ergonomics in laparoscopic surgery / F. M. Sánchez-Margallo, J. A. Sánchez-Margallo. IntechOpen, 2017. - URL : https://doi.org/10.5772/66170. 
15. Guidelines for perioperative care for liver surgery: Enhanced Recovery after Surgery (ERAS) society recommendations / E. Melloul, M. Hübner, M. Scott [et al.] // World. J. Surg. - 2016. Vol. 40 (10). - P. 2425-2440.

16. Impact of risk factors for prolonged operative time in laparoscopic cholecystectomy / M. Zdichavsky, Y. A. Bashin, G. Blumenstock [et al.] // Eur. J. Gastroenterol. Hepatol. - 2012. Vol. 24 (9). - P. 1033-1038.

17. Impact of seniority on operative time and short-term outcome in laparoscopic cholecystectomy: Experience of an academic Surgical Department in a developing country /

\section{REFERENCES}

1. Huang, J., Chang, C.H., Wang, J.L., Kuo, H.K., Lin, J.W., Shau, W.Y., \& Lee, P.H. (2009). Nationwide epidemiological study of severe gallstone disease in Taiwan. BMC. Gastroenterol., 9, 63. DOI: https://doi.org/10.1186/1471-230X-9-63.

2. Lee, S.W., Yang, S.S., Chang, C.S., \& Yeh, H.J. (2009). Impact of the Tokyo guidelines on the management of patients with acute calculous cholecystitis. J. Gastroenterol. Hepatol., 24 (12), 1857-1861. DOI: https://doi.org/10.1111/j.1440-1746.2009.05923.x.

3. Mehta, H.B., Dimou, F., Adhikari, D., Tamirisa, N.P., Sieloff, E., Williams, T.P., ..., \& Riall, T.S. (2016). comparison of comorbidity scores in predicting surgical outcomes. Medical Care, 54 (2), 180-187. DOI: https://doi.org/10.1097/MLR.0000000000000465.

4. Törnqvist, B., Waage, A., Zheng, Z., Ye, W., \& Nilsson, M. (2016). Severity of acute cholecystitis and risk of iatrogenic bile duct injury during cholecystectomy, a population-based casecontrol study. World J. Surg., 40 (5), 1060-1067. DOI:https://doi. org/10.1007/s00268-015-3365-1.

5. Mitchell, C., \& Prabhu, M. (2013). Pelvic inflammatory disease: current concepts in pathogenesis, diagnosis and treatment. Infect. Dis. Clin. North Am., 27 (4), 793-809. DOI: https://doi.org/10.1016/j.idc.2013.08.004.

6. Sparic, R., Mirkovic, L., Malvasi, A., \& Tinelli, A. (2016) Epidemiology of Uterine Myomas: A Review. Int. J. Fertil. Steril., 9 (4), 424-435. DOI:https://doi.org/10.22074/ijfs.2015.4599.

7. Zhulkevych, I.V., \& Kryvokulsky, B.D. (2018). Personalizatsiiav onkolohii: indyvidualnyi pidkhid do profilaktyky tromboembolichnykh uskladnen pry panhisterektomii [Personalization in oncology: individual approach to the prevention of thromboembolic complications during hysterectomy]. Visnyk sotsialnoi hihiieny ta orhanizatsii okhorony zdorovia Ukrainy - Bulletin of Social Hygiene and Health Care Organization of Ukraine, 4 (78), 11-18. DOI: https:// doi.org/10.11603/1681-2786.2018.4.9875 [in Ukrainian].

8. Kryvokulsky, B.D., Zhulkevich, I.V., Kryvokulsky, D.B., \& Shkrobot, L.V. (2018). Vyvchennia vplyvu viku ta indeksu komorbidnosti na ryzyk trombotychnykh uskladnen u khvorykh na rak endometriia na dooperatsiinomu etapi [Studying the influence of age and comorbidity index on the thrombotic complications risk in patients with endometrial cancer at preoperative stage]. Visnyk naukovykh doslidzhen - Bulletin of Scientific Research, 2 (91), 151-153. DOI: https://doi. org/10.11603/2415-8798.2018.2.9212 [in Ukrainian].

9. Sparić, R., Hudelist, G., Berisava, M., Gudović, A., \& Buzadzić, S. (2011). Hysterectomy throughout history. Acta Chir. Iugosl., 58 (4), 9-14.

10. Nelson, G., Bakkum-Gamez, J., Kalogera, E., Glaser, G., Altman, A., Meyer, L. A., \& Taylor, J. (2019). Guidelines for perioperative care in gynecologic/oncology: Enhanced Recovery after Surgery
A. Souadka, M. S. Naya, B. Serji [et al.] // J. Minim. Access Surg. - 2017. - Vol. 13 (2). - P. 131-134.

18. Predicting conversion from laparoscopic to open cholecystectomy: a single institution retrospective study / S. Al Masri, Y. Shaib, M. Edelbi [et al.] // World J. Surg. - 2018. Vol. 42. - P. 2373-2382.

19. Міністерство охорони здоров'я України. Наказ № 428 від 08.04.2014 р. Державні санітарні норми та правила «Гігієнічна класифрікація праці за показниками шкідливості та небезпечності фракторів виробничого середовища, важкості та напруженості трудового процесу». Реєстрація в Міністерстві юстиції України № 472/25249 від 06.05.2014.

(ERAS) society recommendations-2019 update. Int. J. Gynecol. Cancer., 29 (4), 651-668. DOI: https://doi.org/10.1136/ijgc-2019-000356.

11. Guan, J., Karsy, M., Brock, A.A., Couldwell, W.T., \& Schmidt, R.H. (2018). Overlapping Surgery: 2 Years Later. Neurosurgery, 65 (CN_suppl_1), 55-57. DOI: https://doi.org/10.1093/neuros/nyy105.

12. Levin, P.E., Moon, D., \& Payne, D.E. (2017). Overlapping and concurrent surgery: a professional and ethical analysis. J. Bone Joint Surg. Am., 99 (23), 2045-2050. DOI: https://doi. org/10.2106/JBJS.17.00109.

13. Yamashita, Y., Takada, T., Kawarada, Y., Nimura, Y., Hirota, M., Miura, F., Mayumi, T. et.al. (2007). Surgical treatment of patients with acute cholecystitis: Tokyo Guidelines. J. Hepatobiliary Pancreat. Surg., 14 (1), 91-97. DOI: https://doi. org/10.1007/s00534-006-1161-X.

14. Sánchez-Margallo, F.M., \& Sánchez-Margallo, J.A. (2017). Ergonomics in laparoscopic surgery. Intechopen. DOI:10.5772/66170.

15. Melloul, E., Hübner, M., Scott, M., Snowden, C., Prentis, J., Dejong, C. H., ..., \& Demartines, N. (2016). Guidelines for perioperative care for liver surgery: Enhanced Recovery after Surgery (ERAS) society recommendations. World J. Surg., 40 (10), 2425-2440. DOI: https://doi.org/10.1007/s00268-016-3700-1.

16. Zdichavsky, M., Bashin, Y.A., Blumenstock, G., Zieker, D., Meile, T., \& Königsrainer, A. (2012). Impact of risk factors for prolonged operative time in laparoscopic cholecystectomy. Eur. J. Gastroenterol. Hepatol., 24 (9), 1033-1038. DOI: https://doi. org/10.1097/MEG.0b013e328354ad6e.

17. Souadka, A., Naya, M.S., Serji, B., El Malki, H.O., Mohsine, R., Ifrine, L., ..., \& Benkabbou, A. (2017). Impact of seniority on operative time and short-term outcome in laparoscopic cholecystectomy: Experience of an academic Surgical Department in a developing country. J. Minim. Access Surg., 13 (2), 131-134. DOI: https://doi.org/10.4103/0972-9941.186687.

18. Al Masri, S., Shaib, Y., Edelbi, M., Tamim, H., Jamali, F., Batley, N., Faraj, W., Hallal, A. (2018). Predicting conversion from laparoscopic to open cholecystectomy: a single institution retrospective study. World J. Surg., 42, 2373-2382. DOI: https:// doi.org/10.1007/s00268-018-4513-1.

19. Ministry of Health of Ukraine. Order № 428 of 08.04.2014. Derzhavni sanitarni normy ta pravyla «Hihiienichna klasyfikatsiia pratsi za pokaznykamy shkidlyvosti ta nebezpechnosti faktoriv vyrobnychoho seredovyshcha, vazhkosti ta napruzhenosti trudovoho protsesu» [State sanitary norms and rules "Hygienic classification of labor on the indicators of harmfulness and danger of factors of the production environment, the severity and intensity of the labor process"]. Registration in the Ministry of Justice of Ukraine No. 472/25249 of May, 06, 2014 [in Ukrainian].

Отримано 26.08.20

Прийнято до друку 30.09.20

Електронна адреса для листування: galej.mm@gmail.com 